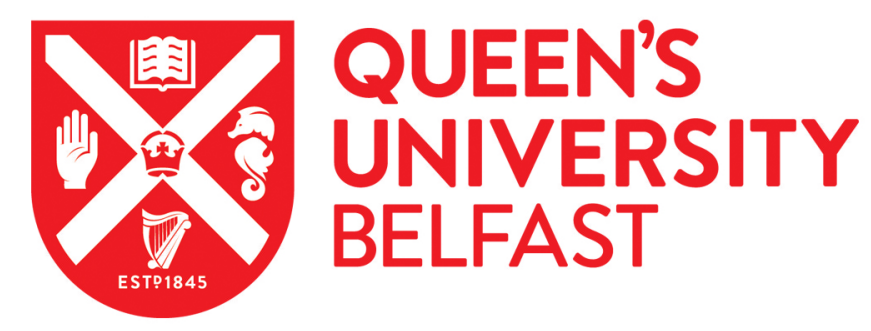

\title{
Dealing with difficult pasts: the role of public history in post-conflict Northern Ireland
}

Purdue, O. (2020). Dealing with difficult pasts: the role of public history in post-conflict Northern Ireland. Studia Hibernica, 46(1), 91-97. https://doi.org/10.3828/sh.2020.7

\author{
Published in: \\ Studia Hibernica
}

\section{Document Version:}

Peer reviewed version

Queen's University Belfast - Research Portal:

Link to publication record in Queen's University Belfast Research Portal

Publisher rights

(C) 2020 Liverpool University Press.

This work is made available online in accordance with the publisher's policies. Please refer to any applicable terms of use of the publisher.

\section{General rights}

Copyright for the publications made accessible via the Queen's University Belfast Research Portal is retained by the author(s) and / or other copyright owners and it is a condition of accessing these publications that users recognise and abide by the legal requirements associated with these rights.

Take down policy

The Research Portal is Queen's institutional repository that provides access to Queen's research output. Every effort has been made to ensure that content in the Research Portal does not infringe any person's rights, or applicable UK laws. If you discover content in the Research Portal that you believe breaches copyright or violates any law, please contact openaccess@qub.ac.uk. 
Studia Hibernica 46

https://www.liverpooluniversitypress.co.uk/journals/issue/5876

Dealing with difficult pasts: the role of public history in post-conflict Northern Ireland Olwen Purdue

(Queen's University Belfast)

When I took up my first permanent lectureship in History at Queen's University Belfast almost a decade ago, one of the first things I was asked to take on and develop was a new Public History Internship module which had recently been set up as part of the Master's degree in History. I have to admit to being rather hesitant - public history was, at that stage, very much an unknown factor and not part of the university curriculum in most universities in the UK or Ireland. I wasn't sure what it involved, but it definitely looked like an exciting programme and, of course, I agreed.

Since those early days, the teaching of public history has gone from strength to strength and in 2017 Queen's launched a Master's degree in Public History and established the Centre for Public History which provides a space for scholarly debate and collaboration on public history in its many manifestations. The institutional support this initiative has received, and the ever-increasing number of Irish and UK universities now offering Public History programmes, is an indication of just how far we've come in recognising the value of public history as a field worth academic attention. In this, we are finally catching up with places like New Zealand and Australia, or North America where the National Council on Public History has been providing a scholarly forum for academics and public history professionals for the past forty years. Despite this increased attention, however, there still remains a degree of uncertainty surrounding public history. In this paper I will explore what I think public history is and can be and why it has an important place in our university curricula as well as reflecting on the particularly important role it plays in divided or conflictaffected societies such as Northern Ireland.

In short, I see public history as history that is being put to work in the public sphere, history created with and for public audiences as opposed to being directed at other 
academics. One of the most prominent academics to have embraced the field, Professor Ludmilla Jordanova, has suggested that public history is actually something many academic historians are doing anyway in sharing our research findings with audiences outside academia. But she encourages us to adopt a broader and more inclusive definition of public history which goes beyond public engagement by academics to encompass 'all the means, deliberate and otherwise, through which those who are not professional historians acquire their senses of the past' ${ }^{1}$

Importantly, public history is scholarly history. There are still some within the academic world who regard public history as simply a dumbing down of the discipline, the rise of the twitterstorian and the telly don heralding the demise of serious academic research and traditional scholarly outputs. In 2012, Professor Sir Keith Thomas, presenting the Wolfson History Prize, referred to what he described as the damage being done to 'diligent' scholarship by 'eye-catching academics'. ${ }^{2}$ Just recently, I heard the contents of an excellent public history grant application being described by an academic from a different institution as 'history lite'. But for all those who see it as a threat to serious academic scholarship, there are many more who recognise the very important intellectual part public history plays in academia as well as in wider society. As the National Council on Public History states, the 'intellectual approach, the theory and methodology of public history remain firmly in the discipline of history, and all good public history rests on sound scholarship'. Several journals, such as The Public Historian and International Public History, are dedicated to the field, while publishers such as Routledge are developing series dedicated to public history as it is practiced and researched internationally. An important acknowledgement of the scholarly significance of public history came in 2015 when the Royal Historical Society introduced its Public History Prize to recognise work 'that promotes public understanding of history and communicates a critical understanding of the past' ${ }^{4}$

The key word here is critical. History is all around us and is often used in the public sphere for present and political purposes. This is a global phenomenon - politicians and

\footnotetext{
${ }^{1}$ Ludmilla Jordanova, 'Public History', History Today, May 2000, 20

2 Peter Stanford, 'Why telly-dons like David Starkey, Lucy Worsley and Bettany Hughes get top marks', The Telegraph, 10 May 2012

3 'How do we define public history?', National Council on Public History website, https://ncph.org/what-ispublic-history/about-the-field/, accessed 3 Feb. 2020.

${ }^{4}$ Royal Historical Society website, https://royalhistsoc.org/prizes/public-history-prize/ accessed 27 Feb. 2020.
} 
public leaders draw on versions of the past to validate both their policies and themselves; images of past events or historical figures symbolically occupy public space. There are real problems surrounding the often suspect ways in which history is used and abused misunderstanding of historical contexts can lead to erroneous and even dangerous assumptions about the past that easily find their way into contemporary civil and political discourse and shape the way people understand the world around them. Past events are frequently called upon and used by different groups to explain and justify their positions and their attitudes towards each other, but so often this is in ways that are reductionist, or selective, that pick the particular parts of the historical canon that fit the narrative they embrace, that fail to grasp or engage with the complexities and nuance of history as it actually was. In this era of fake news and fake history, of issues around nationality and nationalism, and - as we've seen in the United States with the issue of confederate statues increasing political tensions over what we memorialise, how we memorialise it, and where we memorialise it, critical engagement with the past based on scholarship, communicated to wide public audiences, is of vital importance. I would go so far as to say that there is an imperative on historians to work within the public arena, engaging with public audiences to challenge and disrupt commonly accepted or distorted narratives and encouraging more nuanced and historically thoughtful ways of looking at the present through the lens of the past.

Public history is also collaborative. We need to go further than just seeing public history as a means through which academic historians share their knowledge with the public audiences for a variety of purposes. Such an approach is problematic as it suggests placing the historian, or the curator, firmly in the role of authority, presenting a particular narrative to a receptive and passive audience. Rather, the best public history often occurs where academic historians work in meaningful and genuinely collaborative ways with professionals in public, cultural or heritage contexts to build public history initiatives together. It can also involve collaboration at a local or community level when the academic practice of the discipline meets the public's particular interest in their own past or that of others, a place of shared exploration and discovery in which professional historians bring the skills and tools, and possibly the frameworks, but individuals and communities bring the knowledge, insights, perspectives and hopefully enthusiasm that bring any project to life. This is nothing 
new - twenty years ago Michael Frisch was advocating public participation in history-making through oral history as a tool for breaking down institutional barriers. ${ }^{5}$ This was seen at the time as a paradigm shift in how the practice of history was perceived; but now ideas such as 'shared authority' have become a recognised means by which historians and public history institutions seek to know more about the past. Cultural geographer, Hilary Geoghegan, has argued for the same approach to be taken to her subject, stating that

participation in the co-production, communication and application of historical knowledge by geographers, enthusiast communities, the public and interested institutions is central to ensuring the continued value and vibrancy of historical geography in the twenty-first century. ${ }^{6}$

Finally, public history is necessary, particularly in post-conflict regions such as Northern Ireland where societies remain deeply divided and the past is painful and contested. In these contexts, it is so important to have academic historians engaging with public audiences in a way that is truly collaborative, that challenges dangerous reductionist and partisan historical narratives, and that allows space to face up to past trauma. In Ireland, as in many other contexts, history is closely tied to identity. The conflict in Northern Ireland, for example, is often presented as having been founded on mutually exclusive historical and cultural traditions, something that finds its way into political discourse as well as being represented visually on the streets of towns and cities. Historical moments such as the battles of the Boyne or the Somme, the Great Famine or the or the Easter Rising are depicted in ways which strip away all complexity and nuance, all debates about causation, impact and the role of ideology. It is, of course, in this very over-simplification of the past that its symbolic capital lies. Moments, events and figures from history are appropriated and depicted in binary or monochromatic tones in order to reinforce identity and mark

\footnotetext{
${ }^{5}$ Michael H. Frisch, A shared authority: essays on the craft and meaning of oral and public history (Albany, 1990)

${ }^{6}$ Hilary Geoghegan, 'A new pattern for historical geography: working with enthusiast communities and public history', Journal of Historical Geography 46 (2014), 105-7
} 
territory, to denote community and belonging for those on the inside or the 'otherness' of those on the outside, to legitimise a particular present view of society, culture, and politics.

This very divisive sense of the past creates considerable challenges for the practice of public history in Northern Ireland - how do we represent the history of a place or a people to the general public, or engage the public in a shared exploration of their past, when the prevailing historical narratives of that public are deeply contested? In Ireland we are approaching the end of the 'Decade of Centenaries', a ten-year period of public engagement activities around the series of very divisive events that took place one hundred years ago. While much of this has encouraged a more nuanced and inclusive reflection on historical events, some of the most difficult centenaries are yet to come, in particular partition and the civil war. These are therefore interesting times to be thinking about issues such as memory, commemoration and identity, about the relationship between the past and the present, between our history and our politics. And, importantly, about the part that public history can play in helping societies face up to difficult or contentious pasts, dealing with trauma, or facilitating a more engaged and informed approach to contemporary issues. It also provides a valuable opportunity to reflect on the current public history landscape in Northern Ireland today, particularly with regard to the history of the 'Troubles', a conflict that resulted in 3,600 deaths, thousands of life-changing injuries, and deep and lasting trauma.

As Elizabeth Crooke has pointed out, museums and heritage sites in Northern Ireland have traditionally dealt with the history of the conflict largely by avoiding it. She points to the example of Fermanagh County Museum in Enniskillen, a town rocked in 1987 by an IRA bomb at the Remembrance Day ceremony that killed eleven and injured another sixty-four people. Despite the huge impact this had on the community, more than a decade later the event still had not been reflected in the museum's collections. ${ }^{7}$ Belfast City Council has sought to deflect attention from the city's history of conflict by the development of a major visitor attraction, and the establishment of a 'quarter' within the city dedicated to the building, and sinking, of the Titanic. $^{8}$ Meanwhile, it was not until 2009 that the Ulster

\footnotetext{
${ }^{7}$ Elizabeth Crooke, 'Confronting a troubled history: which past in Northern Ireland's museums?', International Journal of Heritage Studies, 7:2 (2001), 120

${ }^{8}$ Brendan Murtagh, Philip Boland and Peter Shirlow, 'Contested heritages and cultural tourism', International Journal of Heritage Studies 23:6 (2017), 508
} 
Museum, part of National Museums of Northern Ireland, made its first attempt to tackle the history of the conflict with the opening of a gallery on 'The Troubles', and when it did, the result drew heavy criticism. As a state-run and funded institution, the museum was very conscious of the need to remain neutral. The conflict was represented only through black and white photographs of key events accompanied by minimal factual text, with no attempt at presenting an interpretive narrative and no use of artefacts. It was, as Frank O'Connor pithily wrote in the Irish Times, a case of 'the past defeating the present ... for fear of giving offence [or] causing controversy'. ${ }^{9}$ In trying to maintain a balanced and neutral representation, the Troubles gallery ended up being bland, sterile and largely failed to engage public audiences.

Other museums such as the Museum of Orange Heritage in Armagh or the Irish Republican Museum at Conway Mill, Belfast, which are run by local communities or organisations, have taken a very different approach, representing specific versions of the past for a particular purpose. The Museum of Free Derry, for example, opened in 2006 on the exact site of the events of Bloody Sunday, the day in 1972 when British soldiers opened fire on a group of protesters, shooting twenty-six people and killing thirteen. The museum opened with the clear purpose of telling the story of what happened on that day from the perspective of the community that was affected, and campaigning for the soldiers concerned to be prosecuted.

So is there a middle ground between a bland, neutral, largely ineffective representation of the Troubles, or else the very partisan, community-run representations of a single narrative? Is there a positive role for public history in Ireland today? I would argue that public history has a hugely important part to play in post-conflict or conflict-affected societies. In Northern Ireland we are beginning to see some really interesting work being carried out in the public history sphere which is helping to disrupt some of the simplistic or exclusive narratives and creating space for dialogue and engagement with shared, and opposing, senses of the past. As we move away from binary and selective uses of the past to a deeper, more nuanced exploration of social issues and human cost, there is a growing awareness that communities do not have different pasts but share a common past. The

\footnotetext{
${ }^{9}$ Irish Times, 24 Dec. 2009.
} 
Wave Trauma Centre, for example, has recently launched its 'Stories from Silence' initiative, in which it collects and makes available oral history testimonies from those who lost loved ones as a result of the Troubles. ${ }^{10}$ As discussed in more detail by Bright, Dolan and Doughty, the Prisons Memory Archive, developed by researchers at Queen's University, has collected film and oral history from a broad range of people connected with the prison system during the conflict and is now working with the Public Records Office to make this material available to public audiences. ${ }^{11}$ And the Ulster Museum is now setting the agenda in terms of how museums can deal with conflict, working collaboratively both with academics and with the community, adopting new approaches in its collecting, interpretation and programming strategies, and rethinking the role that museums can and should be playing in divided societies. Importantly, where it once sought neutrality above all else, it is now clearly stating that a museum is not a neutral space. Rather it a space that provokes; one where ideas, preconceptions and prejudices are challenged rather than avoided or reinforced; one that encourages dialogue, discussion, even dissention; and one that provides a safe space in which to face up to difficult pasts.

The new 'Troubles and Beyond' gallery in the Ulster Museum, opened in 2018, represents an important addition to the growing number of exhibitions and museums emerging globally in response to conflict, violence and trauma, such as the National Museum of Memory which opened in Bogotá in 2015, the Museum of Memory and Human Rights in Santiago, Chile, and, in the United States, the Holocaust museum, the Ground Zero memorial museum or the African-American Museum of History and Culture. ${ }^{12}$ Where the old Troubles gallery was monochromatic and two dimensional, the new 'Troubles and Beyond' gallery is collection-based and rich in the social history of the period. It has been developed in collaboration with academics through an Academic Advisory Committee, and with local communities through an extensive programme of community engagement and collection which has sought to extend the museum's existing collection and to take it beyond the walls of the museum. The focus of the programme, and of the resulting gallery was, in curator Karen Logan's words, about 'going beyond the political narrative to

\footnotetext{
${ }^{10}$ Wave Trauma Centre, 'Stories from Silence', https://wavetraumacentre.org.uk, accessed 15 Feb 2020

${ }^{11}$ https://prisonsmemoryarchive.com

${ }^{12}$ Amy Sodaro, Exhibiting atrocity: memorial museums and the politics of past violence, (New Brunswick, 2018)
} 
represent broader social, cultural and economic history as well as exploring the impact of conflict on everyday life, people and communities'. ${ }^{13}$

The public response has been overwhelmingly positive. Some items on display such as weapons, uniforms, banners etc, relate specifically to the conflict, while others such as maps of no-parking zones or tickets for a Stiff Little Fingers concert allude to the shared everyday life of the people of Northern Ireland. All are exhibited alongside political posters and ephemera and are accompanied by a written narrative which provides the context for the objects and images on display. Some of the items speak to the hurt and grievances of one community or the other. Others bear testimony to the universality of the trauma - an entry in the Ulster-American Folk Park's visitor book by a 16-year-old Spanish boy who was killed in the Omagh bomb the following day, or an art installation composed of torn pieces of red fabric, each torn piece representing a life lost during the conflict with no hierarchy of suffering. Some of the images and objects speak to individuals' or communities' very specific memories or experiences, while others draw in people of all backgrounds into a shared remembering. Some of the objects on display are reaffirming in their familiarity; others, which speak of a different experience of the conflict, challenge and disturb, creating a sense of discomfort and possibly stronger emotions in the visitor. But it is in this capacity to turn the spotlight on past and ongoing trauma in an ethical way, and to provide the space for people to reflect on their responses as they bring their particular perspectives to the objects on display, that the power of the gallery lies.

Public history, therefore, has a hugely important part to play in today's society, and particularly so in societies where the past continues to resonate in divisive and painful ways. Engaging with the public in developing a richer, more nuanced, understanding of such pasts, and communicating these pasts to public audiences, is challenging. But it is also vitally important. Forgetting is a very dangerous thing - whether in Ireland or in many other parts of the world, we can very easily forget where we've come from and take our relative peace and stability for granted; as Cecile Gordon and Brian Crowley emphasise here, writing from their perspectives as archivists and curators, voices can be drowned out of the narrative,

\footnotetext{
${ }^{13}$ Karen Logan, 'Collecting The Troubles and Beyond: the role of the Ulster Museum in interpreting contested history', arthistoricum.net (2019), https://books.ub.uniheidelberg.de/arthistoricum/reader/download/428/428-17-84269-1-10-20190314.pdf accessed 3 Feb 2020
} 
and some have never been heard. It is up to us historians, therefore, to engage in the public sphere in a way that is scholarly, collaborative and impactful in order to disrupt simplistic narratives, give voice to those that have remain unheard, deepen and enrich public engagement with and understanding of the past, and create a place where shared, and opposing, senses of the past can be explored in thoughtful and sensitive ways. 